\title{
A pars petrosa cholesteatomák korszerü ellátása
}

\author{
Pécsi tapasztalatok
}

\author{
Gerlinger Imre dr. ${ }^{1}$ - Végh Ildikó dr. ${ }^{1}$ - Nepp Nelli dr. ${ }^{1}$ \\ Pap István dr. ${ }^{1}$ - Révész Péter dr. ${ }^{1}$ - Bakó Péter dr. ${ }^{1}$ - Szanyi István dr. ${ }^{1}$ \\ Rostás Tamás $\mathrm{dr}^{2}{ }^{2}$. Tóth István $\mathrm{dr}^{1}$
}

${ }^{1}$ Pécsi Tudományegyetem, Általános Orvostudományi Kar, Fül-, Orr-, Gégészeti és Fej-, Nyaksebészeti Klinika, Pécs

${ }_{2}^{2}$ Pécsi Tudományegyetem, Általános Orvostudományi Kar, Radiológiai Klinika, Pécs

\begin{abstract}
A pars petrosa cholesteatoma egy lassan növekvő, a temporalis csontot roncsoló, elhúzódóan tünetmentes kórkép. A diagnózis felállítása gyakran késlekedik, hiszen ritka volta miatt még a tapasztalt klinikusok sem gondolnak rá időben. A végső diagnózist jellemzően számos eredménytelen középfülsebészeti beavatkozás előzi meg. A modern radiológiai módszerek nemcsak a diagnózist, hanem a betegek hosszú távú követését is lehetővé teszik. Retrospektív klinikai tanulmányunkban a pars petrosa cholesteatomák sikeres mútéti kezelésére kívánjuk felhívni a figyelmet, hazai beteganyagon első alkalommal elemezve a mütéti megoldások eredményességét. Kezdeti tapasztalatainkat a nemzetközi irodalomból nyerhető adatokkal hasonlítottuk össze. 2015 januárja és 2020 januárja között 6 beteget (4 férfi, 2 nő) kezeltünk különböző lokalizációjú pars petrosa cholesteatomával. Valamennyi beteg a cholesteatoma lokalizációjának megfelelő agyalapi sebészeti beavatkozáson esett át. A betegek átlagos követési ideje 2,7 év volt. A betegek átlagéletkora 47 év volt. A leggyakoribb panaszok a halláscsökkenés, gennyes fülfolyás, szédülés, fülzúgás voltak. Egy beteg már a felvételekor a komplett facialis paralysis tüneteit mutatta. A Sanna-féle osztályozás szerint 2-2 betegünk szenvedett supralabyrinthaer, illetve apicalis, 1-1 beteg pedig masszív, illetve infralabyrinthaer pars petrosa cholesteatomában. Komplikáció sem a peri-, sem a posztoperatív időszakban nem fordult elő. Egy betegnél észleltük a residualis betegség radiológiai jeleit. A pars petrosa cholesteatoma diagnózisa és terápiája komoly nehézséget jelent még a tapasztalt klinikusok számára is. A korai diagnózist a nem jellegzetes tünettan ismerete és a modern képalkotó modalitások teszik lehetôvé. A sziklacsontot roncsoló patológiás folyamat eltávolítására korszerű agyalapi sebészeti módszerek állnak rendelkezésre. Ezek a mútétek napjainkban kombinálhatók a modern hallásrehabilitációs módszerekkel.
\end{abstract}

Orv Hetil. 2020; 161(43): 1840-1848.

Kulcsszavak: agyalapi sebészet, bulbus venae jugularis, arteria carotis interna, dura mater, hallásrehabilitáció, nervus facialis, pars petrosa cholesteatoma

\section{Modern management of pars petrosa cholesteatomas}

\section{Experiences in Pécs}

Petrous bone cholesteatoma is a slowly growing, extensively asymptomatic temporal bone destroying disease. Even the most experienced clinicians do not consider this rare disease in time, delaying its diagnosis. This is often preceded by a number of unsuccessful middle ear surgeries. Modern radiological techniques allow not only an accurate diagnosis but also assist in the long-term follow-up of patients. The aim of our retrospective clinical study is to highlight, at a local level, the success of the available surgical treatments for petrous bone cholesteatomas. We also compared our results with those from the international literature. Between January 2015 and January 2020, 6 patients ( 4 men, 2 women) were treated with petrous bone cholesteatomas at different locations. All patients underwent skull base surgery tailored to the location of the cholesteatoma. The mean follow-up of patients was 2.7 years. The mean age of the patient population was 47 years. The most common symptoms were hearing loss, purulent discharge, dizziness, and tinnitus. One patient had already symptoms of complete facial paralysis at the time of admission. According to Sanna's classification, two of our patients had supralabyrinth cholesteatoma, two had apical petrous bone cholesteatoma, one had massive cholesteatoma and one had infralabyrinth cholesteatoma. No complications were 
observed in either the peri- or the postoperative period. Radiological evidence of residual disease was observed in one case. The diagnosis and therapy of petrous bone cholesteatoma is challenging even for the experienced clinician. Early diagnosis is made possible by the awareness of the atypical symptoms and introduction of modern imaging modalities. Modern skull base surgical techniques exist to remove the petrous bone destroying pathology. In addition, these techniques can now be combined with modern hearing rehabilitation methods.

Keywords: dura mater, facial nerve, hearing rehabilitation, internal carotid artery, jugular bulb, petrous bone cholesteatoma, skull base surgery

Gerlinger I, Végh I, Nepp N, Pap I, Révész P, Bakó P, Szanyi I, Rostás T, Tóth I. [Modern management of pars petrosa cholesteatomas. Experiences in Pécs]. Orv Hetil. 2020; 161(43): 1840-1848.

(Beérkezett: 2020. május 1.; elfogadva: 2020. május 21.)

\section{Rövidítések}

3D = háromdimenziós; BAHA = (bone-anchored hearing aid $)$ csontvezetéses implantátum; $\mathrm{CT}=$ (computed tomography) számítógépes tomográfia; $\mathrm{dB}=$ decibel; HRCT = (high-resolution computed tomography) nagy felbontású számítógépes tomográfia; $\mathrm{MRI}=$ (magnetic resonance imaging) mágnesesrezonancia-képalkotás; PPC = pars petrosa cholesteatoma; PTE KK = Pécsi Tudományegyetem, Klinikai Központ

Az os temporale 4 alkotóeleme (pars petrosa, pars squamosa, processus mastoideus, pars tympanica) közül a pars petrosát roncsoló cystosus epidermoid képletet nevezzük pars petrosa cholesteatomának (PPC). A PPC-k lassú növekedésük okán hosszú évekig tünetmentesek lehetnek, egészen addig, amíg nem involválják a labyrinthust vagy a nervus facialist vagy a központi idegrendszert (meningitis, agytályog) [1]. Ezek a cholesteatomák a klasszikus tympanomastoidalis elhelyezkedésen túlmenően medialis irányba nőve, a pars petrosát involválva egészen a sziklacsont csúcsáig terjedhetnek.

A klinikai gyakorlatban előforduló cholesteatomák 3\%-át kitevő PPC-k két nagy csoportra oszthatók: congenitalis és szerzett formákra. A veleszületett formák az egyedfejlődés folyamán a temporalis csont különböző régióiban megbújó epithelialis sejtelemekből származnak. A szerzett formák a tympanomastoidalis régiótól medialisan involválják a pars petrosát [2].



1. ábra

Supralabyrinthaer PPC sémás rajza és CT-felvétele (bal oldal)
CT = számítógépes tomográfia; PPC = pars petrosa cholesteatoma

\section{A pars petrosa cholesteatomák osztályozása}

A Sanna szerinti osztályozás 5 csoportot különít el $[3,4]$ :

I. Supralabyrinthaer cholesteatomák (1. ábra)

II. Infralabyrinthaer cholesteatomák (2. ábra)

III. Masszív cholesteatomák (3. ábra)

IV. Infralabyrinthaer-apicalis cholesteatomák (4. ábra)

V. Apicalis cholesteatomák (5. ábra)

Ezen osztályozás egyúttal meghatározza a sebészi beavatkozás, a helyesen megválasztott agyalapi sebészeti megoldás típusát is. Az elmúlt két évtized során a transpetrosus és a lateralis agyalapi sebészeti megoldások, valamint a korszerű radiológiai módszerek alapvetőn változtatták meg a PPC-k kezelését, szignifikánsan javítva a kellő biztonsággal kivitelezett műtétek sikerességét.

\section{Mütéttechnikai nehézségek}

A cholesteatoma sebészetében a mátrix preparálása, követése általában nem okoz nehézséget, s a cholesteatoma jó eséllyel történő eltávolítása reális cél lehet, feltéve, ha a nehezen belátható területeket (anterior atticus, sinus tympanicus) alaposan átvizsgáljuk (tükör, endoszkóp használata). A gondok akkor kezdődnek, amikor a cholesteatomamátrix nem csontos alaphoz (dura mater, sinus sigmoideus, bulbus venae jugularis, nervus facialis,

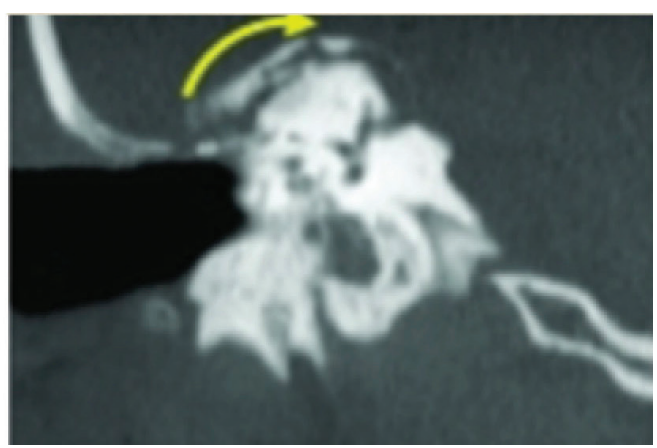



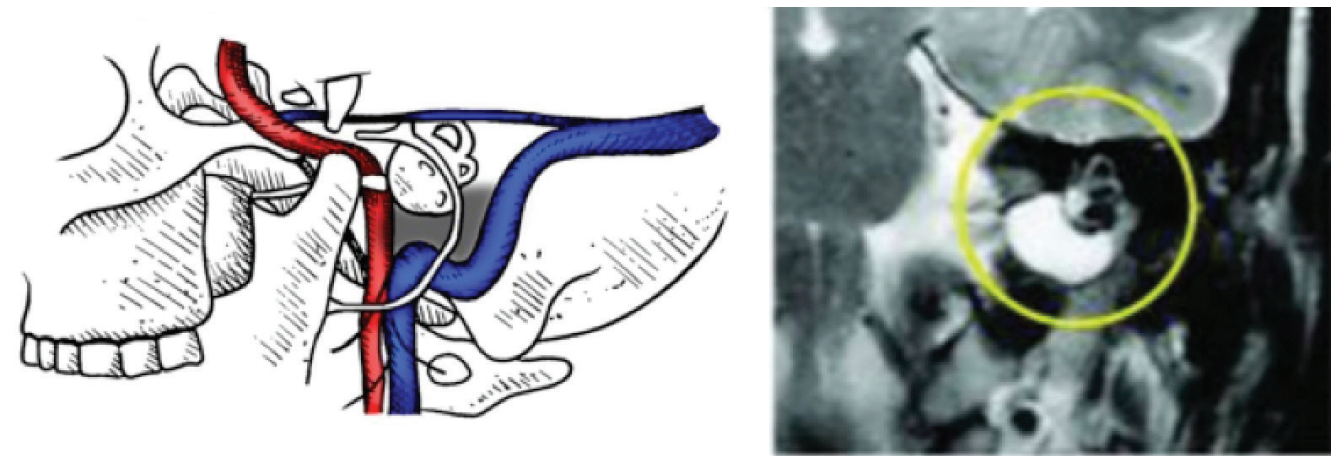

2. ábra

Infralabyrinthaer PPC sémás rajza és MRI-felvétele (bal oldal) MRI = mágnesesrezonancia-képalkotás $; \mathrm{PPC}=$ pars petrosa cholesteatoma
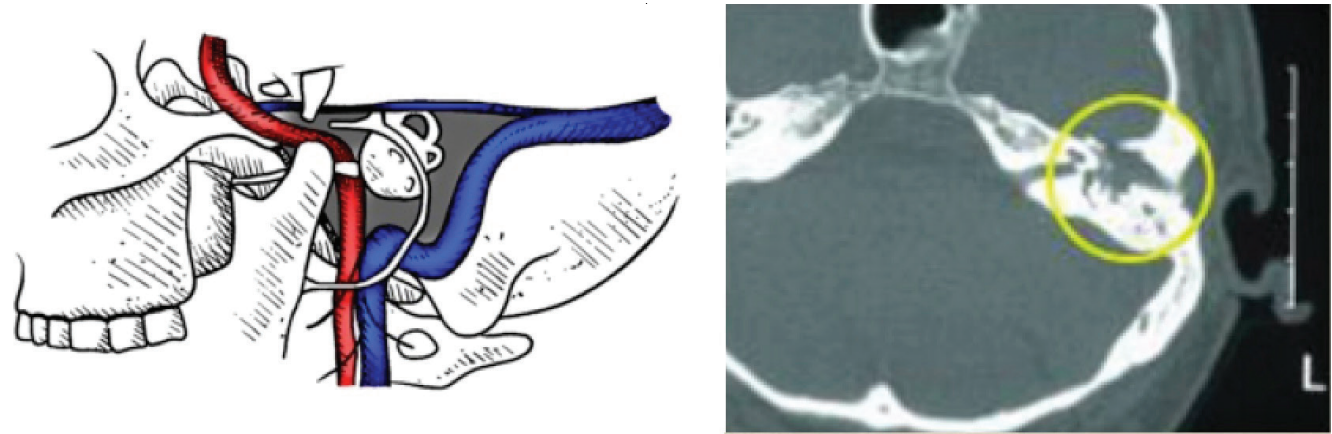

3. ábra

Masszív PPC sémás rajza és CT-felvétele (bal oldal)

$\mathrm{CT}$ = számítógépes tomográfia $; \mathrm{PPC}=$ pars petrosa cholesteatoma
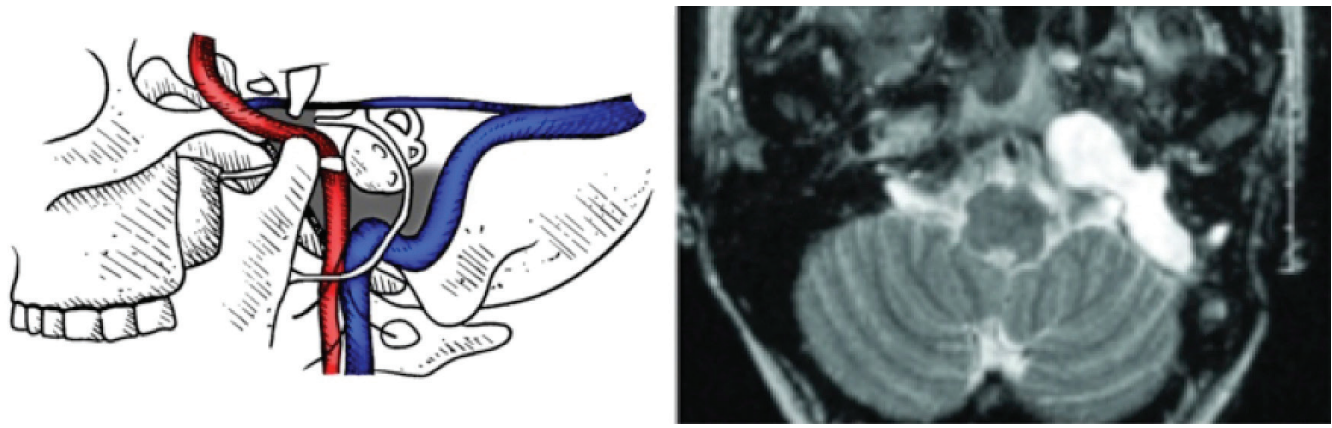

4. ábra

Infralabyrinthaer-apicalis PPC sémás rajza és MRI-felvétele (bal oldal)
MRI = mágnesesrezonancia-képalkotás; PPC = pars petrosa cholesteatoma
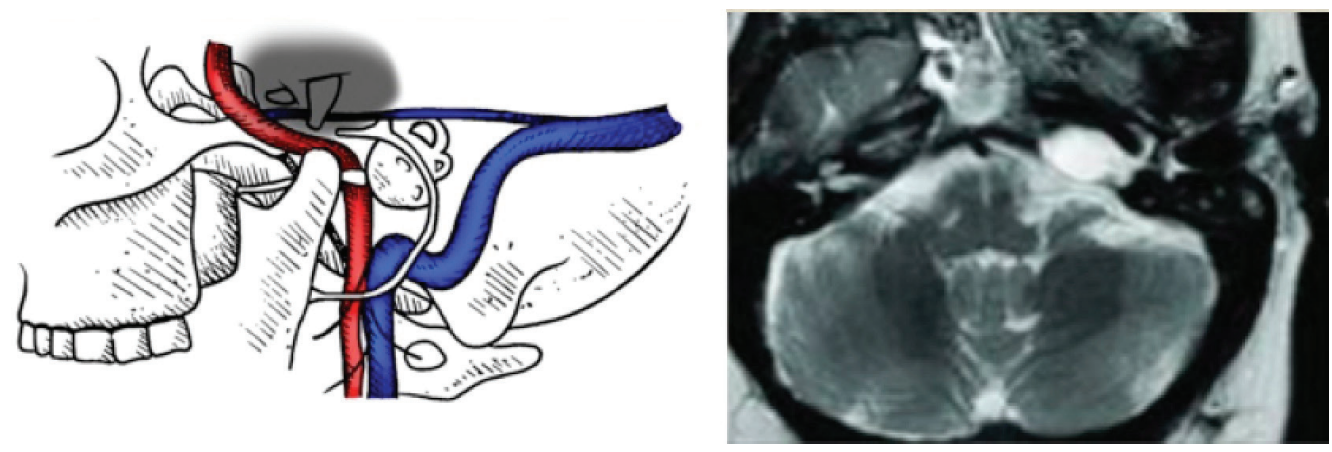

\begin{tabular}{l|l} 
5. ábra & $\begin{array}{l}\text { Apicalis PPC sémás rajza és MRI-felvétele (bal oldal) } \\
\text { MRI = mágnesesrezonancia-képalkotás; } P P C=\text { pars petrosa cholesteatoma }\end{array}$
\end{tabular} 
arteria carotis interna fala) tapad: ezekben az esetekben a mátrix preparálása komoly kihívást jelent a sebész számára $[1,5]$.

\section{A dura mater érintettsége}

Ha a cholesteatomamátrix a dura materhez tapad, akkor a környező csonthatárok alapos eltávolítására van szükség. Amennyiben kétség merül fel a mátrix maradéktalan eltávolítását illetően, óvatos bipoláris koagulációt alkalmazhatunk, ügyelve a dura sérülésének elkerülésére. Alternatív megoldásként - Fisch javaslata alapján - 90\%-os etil-alkoholt használhatunk a mátrix eltávolítására, vagy az érintett dura excisióját követően fasciával/liodurával pótolhatjuk a durahiányt [4].

\section{A sinus sigmoideus és a bulbus venae jugularis érintettsége}

Mindkét képlet fala könnyen sérülhet a cholesteatomamátrix preparálása során. Ilyen esetekben ritkán ugyan, de sor kerülhet a sinus sigmoideus intraluminaris vagy extraluminaris kompressziójára (Surgicel; Johnson \& Johnson, New Brunswick, NJ, USA ), végszükség esetén a vena jugularis ligatúrájára a nyakon. Ilyenkor eltávolítható a cholesteatomamátrixszal beszűrt bulbus vagy a sinus sigmoideus lateralis fala. A bulbus medialis falából eredő sinus petrosus inferior vérzése Surgicel-tamponálással megszüntethető. Mindig győződjünk meg arról, hogy az érintett oldalon a sinus sigmoideus domináns sinus-e, ugyanis a domináns sinus sigmoideus tamponálása fatális következményekkel járhat $[1,5,6]$.

\section{$\mathrm{Az}$ arteria carotis interna érintettsége}

Tekintettel arra, hogy az arteria carotis interna fala vastag, a mátrix preparálása gyakorlott operatőr számára általában nem okoz nehézséget. Az infratemporalis fossa B-típusú feltárás és a módosított transcochlearis behatolások (A-D) során kitűnő hozzáférés adódik a carotis interna vertikális szakaszára, valamint a pars petrosában futó horizontális szakaszra is [6].

\section{A nervus facialis érintettsége}

A PPC-k egyik első tünete lehet a nervus facialis paresise vagy paralysise. Ha már a mútét előtt felmerül a gyanú az arcideg érintettségére, fel kell készülni arra, hogy az operáció során kompresszióval, az ideg megszakadásával találkozunk, ritkán az ideg egy szakasza kötőszövetesen átépült. A mátrix kíméletes eltávolítása általában megoldja a kompressziós tüneteket. Ha a mátrix eltávolítása biztonsággal nem kivitelezhető, akkor az ideg egy szakaszának excisiója elkerülhetetlen. Az ideg széleinek felfrissítését követően a további teendőket a defektus mérete határozza meg: ha a defektus kicsi, akkor az ún. „rerouting” (az ideg kiemelése a csatornájából) után feszülésmentes primer anastomosist végezhetünk [7]. $\mathrm{Ha}$ a defektus nagyobb, akkor szabadon áthelyezett ideggraft és lehetőség szerint biológiai ragasztó alkalmazása a megoldás. Szóba jövő lehetőségként elsősorban a nervus suralist és a nervus auricularis magnust lehet említeni. Ha a páciens jelentkezésekor a facialis paralysis már több mint egy éve fennáll, akkor facialishypoglossus vagy facialis-masseter anastomosis orvosolhatja a problémát [8].

\section{A belső fül és a hallás érintettsége}

A PPC-k eseteiben a mátrix radikális eltávolítása a célunk. A cochlea érintettsége esetén nem kérdés, hogy a mátrix eltávolítása során fel kell áldoznunk az érintett oldali hallást, feltéve, ha az ellenoldalon kielégítő vagy rehabilitálható a cochlea funkciója. A cholesteatomamátrix által érintett egyetlen halló fül komoly dilemmát jelent a klinikusnak. Ilyen esetekben a mátrix hátrahagyása megköveteli a beteg rendszeres audiológiai és radiológiai (CT, diffúziósúlyozott MRI) követését. Progresszív halláscsökkenés esetén elkerülhetetlen a radikális mútéti megoldás. Indokolt esetben a patológia eltávolításával egy időben az ellenoldalon cochlearis implantációt végezhetünk. A mátrix eltávolításakor sor kerülhet az érintett oldalon is cochlearis implantációra. Ha a mátrix megbízhatóan eltávolítható, akkor törekedni kell a cochlea megőrzésére. Sajnálatos módon ezen utóbbi állapot ritkán fordul elő, ugyanis az oticus capsula rendszerint kiterjedten érintett $[5,6]$.

\section{Liquorcsorgás}

Liquorcsorgás akkor fordulhat elő, ha nem kellő óvatossággal preparáljuk le a mátrixot az agyhártyáról. Egy kisebb duradefektust betömhetünk egy izomdarabbal, jelentősebb méretû defektus esetén az izomdugó felett összeölthetjük a sérülésnek megfelelően a dura széleit [6].

\section{Betegek és módszer}

2015. január 1. és 2020. január 1. között 6 beteget kezeltünk a PTE KK Fül-, Orr-, Gégészeti és Fej-, Nyaksebészeti Klinikáján PPC-val. Ugyanezen időszak alatt intézetünkben 214 beteget kezeltünk gennyes fülfolyással járó krónikus purulens cholesteatomás középfülgyulladással, tehát a PPC-k az összes eset 3\%-át alkották. Legfiatalabb betegünk 10 éves volt, a legidősebb 80 éves. Minden beteg esetében a diagnózist követően alapos otoneurológiai vizsgálatra került sor. Protokollunk szerint audiológiai vizsgálatokra a mútétek előtt, majd 3-6 hónappal a mütétek után került sor, ezt követően pedig minden évben. Preoperatív axialis és coronalis síkú, csontablakos HRCT-felvételeket minden bete- 
günknél indikáltunk; néhány esetben T1- és T2-súlyozott, az utóbbi időben diffúziósúlyozott MRI-felvételekre is sor került. Betegeink leggyakoribb panaszai az anacusis, gennyes fülfolyás, vertigo, fejfájás, valamint arcidegbénulás, ritkán egyéb agyideg-érintettségek voltak. A korábban végzett számos, eredménytelen középfülmütét ugyancsak a radiológiai vizsgálatok indikációját jelentette. A betegek követése során az első és a harmadik posztoperatív évben diffúziósúlyozott MR-vizsgálatot indikáltunk.

\section{Eredmények}

6 betegünk közül 4 volt férfi, 2 nő, a betegek átlagéletkora 47 év volt. Betegeink átlagos követési ideje 2,7 év volt. A Sanna-féle klasszifikációt alapul véve 2 betegünk esetében supralabyrinthaer PPC-t diagnosztizáltunk, ugyancsak 2 betegünk szenvedett apicalis PPC-ban. 1-1 betegnél észleltünk infralabyrinthaer, illetve masszív PPC-t. A betegeinkre vonatkozó legfontosabb epidemiológiai adatokat a 1 . táblázatban foglaltuk össze.

6 betegünk közül 5 számos középfülsebészeti beavatkozáson esett át, mielőtt intézetünkbe felvételre kerültek. Négy betegünk esetében már a mütét előtt igen súlyos fokú (80 dB $\leq$ ) kevert halláscsökkenést észleltünk, 1 beteget siketen vettünk fel, l esetben közepes fokú, kevert típusú halláscsökkenés állt fenn. Az általunk végzett mütétek során a patológiás folyamat eradikálása, nem pedig a hallás megőrzése volt a cél.

A mütéteket követően 2 supralabyrinthaer esetünkben cochlearis implantációt alkalmaztunk, az egyoldali siketséggel felvett betegünket 6 hónappal a cholesteatoma eradikálása után BAHA-implantációban részesítettük; a 3 további betegünk nem kívánt további implantációs megoldást.

Betegeink körében a leggyakoribb panaszok a halláscsökkenés (6 eset) és a hosszú ideje fennálló gennyes fülfolyás ( 5 eset) voltak. További gyakori panasz volt a szédülés (5 eset), a gyakori fejfájás (2 eset) és a tinnitus (2 eset). Egy beteg anamnézisében szerepelt a hallójáratból történő, időnként észlelt vérezgetés és liquorcsorgás (1. táblázat).

$\mathrm{Az}$ arcidegfunkciót illetően egy beteget HouseBrackmann VI/VI. fokozatú arcidegbénulással vettünk fel, a másik 5 esetben az arcidegfunkció megtartott volt. A mútéteket követően 2 esetben az arcidegfunkciót meg tudtuk örizni, 2 esetben House-Brackmann III/ VI., l esetben (10 éves fiúgyermek) House-Brackmann VI/VI. fokozatú átmeneti - 5 hónapig tartó - arcidegérintettség alakult ki. A preoperatív komplett facialis paralysissel felvett beteg arcidegstatusa nem változott. Ennél a betegnél - tekintettel a paralysis több mint egyéves voltára - egyéb rekonstrukciós megoldást nem terveztünk.

Mindkét supralabyrinthaer elhelyezkedésű PPC-s betegünk esetében subtotalis petrosectomiát végeztünk (6. ábra). A sziklacsont csúcsát kitöltő 2 , ún. apicalis esetünkben infratemporalis fossa B-típusú mútétet végeztünk, melyet transoticus feltárással egészítettünk ki (7. ábra). Egyetlen infralabyrinthaer PPC-s esetünkben szintén subtotalis petrosectomiát végeztünk (8. ábra). Ugyancsak egyetlen masszív típusú esetünkben módosított transcochlearis behatolást alkalmaztunk (9. ábra).

A leggyakrabban előforduló mútéti komplikációk (arcidegbénulás, a mútéti üreg infekciója, meningokele, liquorfolyás, agytályog) közül mi egyetlen esetben észleltünk átmeneti teljes facialis paralysist, mely 5 hónap

1. táblázat | PPC-ban szenvedő 6 betegünk demográfiai és klinikai adatai

\begin{tabular}{|c|c|c|c|c|c|c|}
\hline Beteg & Kor/nem & Anamnézis & Panasz & Halláscsökkenés & Mútéti lelet & Követés \\
\hline $\mathrm{BI}$ & $70 / \mathrm{ffi}$ & $\begin{array}{l}2 \mathrm{TP}(\mathrm{J}), 1 \mathrm{TP}(\mathrm{B}), \\
1 \text { konz. rad. }(\mathrm{J}) 2 \text { éve }\end{array}$ & $\begin{array}{l}\text { Állandó fülgennyedés, } \\
\text { fülzúgás, szédülés }\end{array}$ & $\begin{array}{l}80 \mathrm{~dB} \text { kevert }(\mathrm{J}), \\
\text { idegi komp. } 45 \mathrm{~dB}\end{array}$ & IL cholest. SP & Primer sebgyógyulás \\
\hline SJ & $80 /$ nő & $3 \mathrm{TP}(\mathrm{B})$ & $\begin{array}{l}\text { Agyvízfolyás, vérzés, } \\
\text { szédülés, gennyes } \\
\text { fülfolyás }\end{array}$ & $\begin{array}{l}90 \mathrm{~dB} \text { kevert }(\mathrm{B}) \text {, } \\
\text { idegi komp. } 50 \mathrm{~dB}\end{array}$ & $\begin{array}{l}\text { SL cholest. } \\
\text { SP, } \\
\text { késóbb CI }\end{array}$ & Primer sebgyógyulás \\
\hline VJ & $33 / \mathrm{ffi}$ & $\begin{array}{l}\text { Retromastoidalis } \\
\text { craniotomia }(\mathrm{J})\end{array}$ & $\begin{array}{l}\text { HB VI/VI FP, } \\
\text { siketség, gennyes } \\
\text { fülfolyás }\end{array}$ & Siket fül $(\mathrm{J})$ & $\begin{array}{l}\text { Masszív cholest. } \\
\text { MTC, } \\
\text { késóbb BAHA }\end{array}$ & $\begin{array}{l}\text { Primer sebgyógyulás, } \\
\text { HB VI/VI. }\end{array}$ \\
\hline $\mathrm{MZ}$ & $39 / \mathrm{ffi}$ & $\begin{array}{l}\text { Tinnitus, vertigo miatt } \\
\text { megfigyelés }\end{array}$ & $\begin{array}{l}\text { Fülzúgás, szédülés, } \\
\text { fejfájás }\end{array}$ & $\begin{array}{l}100 \mathrm{~dB} \text { kevert }(\mathrm{J}) \text {, } \\
\text { idegi komp. } 60 \mathrm{~dB}\end{array}$ & $\begin{array}{l}\text { Apicalis cholest. } \\
\text { ITFB + TO }\end{array}$ & $\begin{array}{l}\text { Primer sebgyógyulás, } \\
\text { HB III/VI. }\end{array}$ \\
\hline $\mathrm{KA}$ & $50 /$ nö & Radikális fülműtét (3×) (B) & $\begin{array}{l}\text { Gennyes fülfolyás, } \\
\text { fejfájás, szédülés }\end{array}$ & $\begin{array}{l}105 \mathrm{~dB} \text { kevert (B), } \\
\text { idegi komp. } 75 \mathrm{~dB}\end{array}$ & $\begin{array}{l}\text { Apicalis cholest. } \\
\text { ITFB + TO }\end{array}$ & $\begin{array}{l}\text { Primer sebgyógyulás, } \\
\text { HB III/VI. }\end{array}$ \\
\hline LG & $10 / \mathrm{ffi}$ & $\begin{array}{l}2 \text { TP }(J) \text {, radikális fülmútét } \\
(\mathrm{I} \times)(\mathrm{J})+\mathrm{I} \times \text { revízió }\end{array}$ & $\begin{array}{l}\text { Gennyes fülfolyás, } \\
\text { szédülés }\end{array}$ & $\begin{array}{l}55 \mathrm{~dB} \text { kevert }(\mathrm{J}), \\
\text { idegi komp. } 20 \mathrm{~dB}\end{array}$ & $\begin{array}{l}\text { SL cholest. } \\
\text { SP, } \\
\text { késóbb CI }\end{array}$ & $\begin{array}{l}\text { Primer sebgyógyulás, } \\
\text { HB VI/VI. } \\
\text { (átmeneti) }\end{array}$ \\
\hline
\end{tabular}

$\mathrm{B}=$ bal fül; $\mathrm{BAHA}=$ csontvezetéses implantátum; cholest. $=$ cholesteatoma; $\mathrm{CI}=$ cochlearis implantáció; $\mathrm{dB}=\mathrm{decibel} ; \mathrm{FP}=$ facialis paresis; $\mathrm{HB}=$ House-Brackmann-skála; IL = infralabyrinthaer; ITFB = infratemporalis fossa B-típusú feltárás; J = jobb fül; konz. rad. = konzervatív radikális fülmütét; $\mathrm{MTC}=$ módosított transcochlearis feltárás; $\mathrm{PPC}=$ pars petrosa cholesteatoma; $\mathrm{SL}=$ supralabyrinthaer; $\mathrm{SP}=$ subtotalis petrosectomia; $\mathrm{TO}=$ transoticus behatolás; $\mathrm{TP}=$ tympanoplastica 


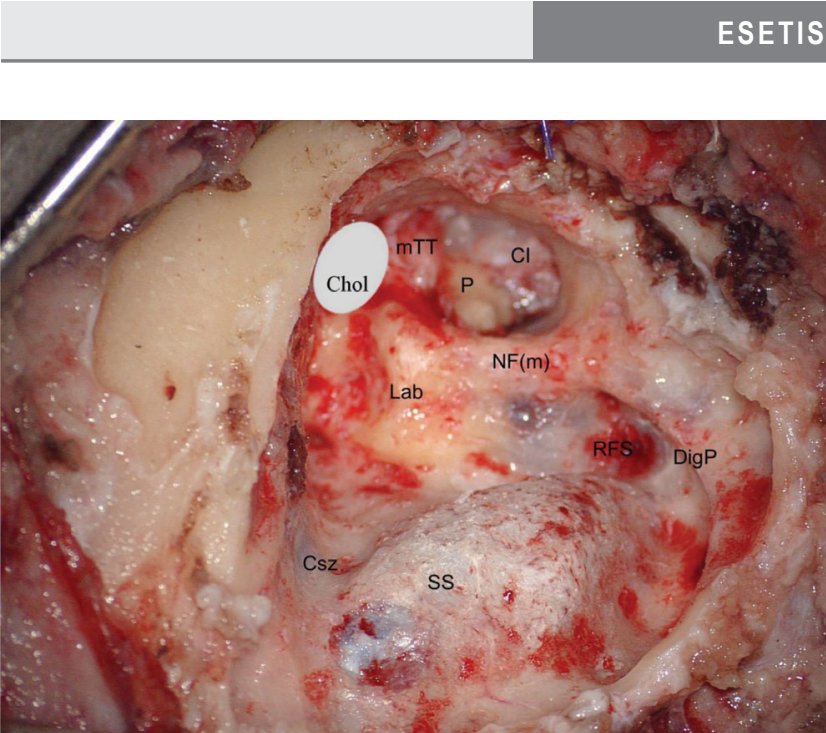

6. ábra Supralabyrinthaer PPC eltávolítása subtotalis petrosectomiáva (szürke folt jelzi a cholesteatoma helyét)

Chol = cholesteatoma; $\mathrm{CI}=$ carotis interna $; \mathrm{Csz}=$ Citelli-szög let; $\mathrm{DigP}=$ digastricus plató; $\mathrm{Lab}=$ labyrinthus; $\mathrm{mTT}=$ musculus tensor tympani; $\mathrm{NF}(\mathrm{m})=$ a nervus facialis mastoidalis szakasza $; \mathrm{P}=$ promontorium $; \mathrm{PPC}=$ pars petrosa cholesteatoma; RFS $=$ retrofacialis sejtek; $S S=$ sinus sigmoideus



7. ábra

Infratemporalis fossa B-típusú műtét és transoticus behatolás kombinálása apicalis PPC eltávolítása során

Chol = cholesteatoma; $\mathrm{CI}=$ carotis interna; $\mathrm{NF}(\mathrm{d})=$ a nervu facialis dobüregi szakasza; $\mathrm{NF}(\mathrm{m})=$ a nervus facialis mastoidalis szakasza $;$ PPC $=$ pars petrosa cholesteatoma

elteltével House-Brackmann III/VI. fokozatúvá mérséklődött. A diffúziósúlyozott MRI segítségével végzett betegkövetés során az egyik apicalis PPC-s betegünk esetében residualis cholesteatoma gyanúja merült fel a carotis interna mentén. Ebben az esetben évente képalkotóval kontrolláljuk a residualis elváltozást, és csak jelentős növekedés esetén kerülne sor ismételt feltárásra. Az ilyen residuumot nem tartjuk komplikációforrásnak, mivel a lezárt mütéti üregben nincs esély a kis vénák retrográd thrombophlebitisére.

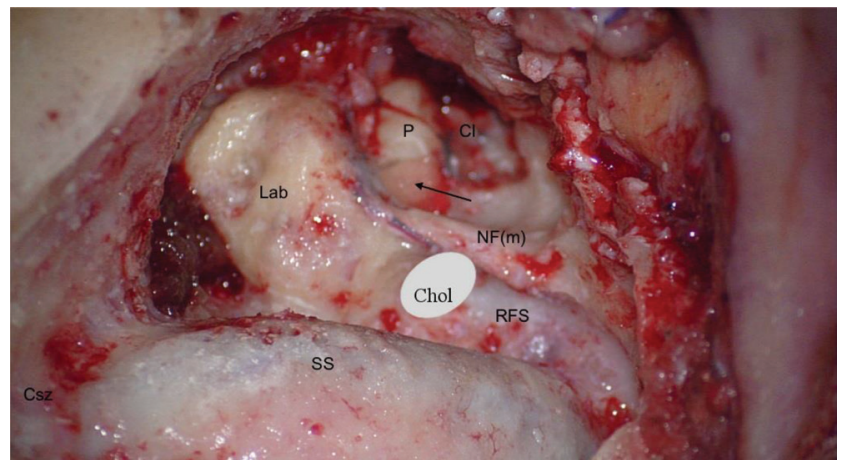

8. ábra

Infralabyrinthaer PPC eltávolítása subtotalis petrosectomiával (szürke folt jelzi a cholesteatoma helyét)

Chol = cholestatoma CI = carotis interna Csz = Citelli-szöglet; $\mathrm{Lab}=$ labyrinthus; $\mathrm{NF}(\mathrm{m})=$ a nervus facialis mastoidalis szakasza; $\mathrm{P}=$ promontorium; $\mathrm{PPC}=$ pars petrosa cholesteatoma; RFS = retrofacialis sejtek; $S S$ = sinus sigmoideus; fekete nyíl: Gelfoam a kerekablak-membránon

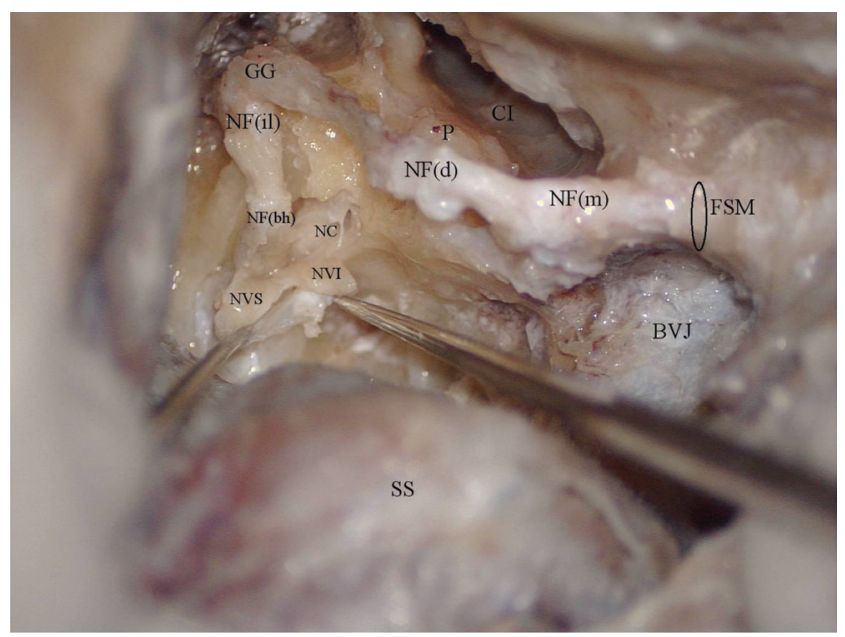

9. ábra

Módosított transcochlearis behatolás cadaverdissectiós felvétele $\mathrm{BVJ}=$ bulbus venae jugularis; $\mathrm{CI}=$ carotis interna; $\mathrm{FSM}=$ fora men stylomastoideum; $\mathrm{GG}=$ ganglion geniculi; $\mathrm{NC}=$ nervus cochlearis; $\mathrm{NF}(\mathrm{bh})=$ a nervus facialis belső hallójárati szakasza; $\mathrm{NF}(\mathrm{d})=$ a nervus facialis dobüregi szakasza; $\mathrm{NF}(\mathrm{il})=$ a nervus facialis intralabyrinthaer szakasza; $\mathrm{NF}(\mathrm{m})=$ a nervus facialis mastoidalis szakasza; NVI = nervus vestibularis inferior; $\mathrm{NVS}=$ nervus vestibularis superior; $\mathrm{P}=$ promontorium; $\mathrm{SS}=$ sinus sig moideus

\section{Megbeszélés}

A klinikum szempontjából a PPC-k osztályozásának jelentőségét nem lehet eléggé hangsúlyozni. Lényeges szempont, hogy a sebészek közös nyelvet beszéljenek, amikor a kórkép kiterjedésétől függően kiválasztják az adott betegre adaptálható megfelelő mütéti behatolást. A Sanna-féle osztályozás jól összefoglalja a pars petrosa érintettségének a cholesteatomamátrix által okozott leggyakoribb változatait, érdemes azonban szem előtt 
tartani, hogy extrém esetekben a cholesteatomamátrix elérheti a clivust, a sinus sphenoidalist és az orrgaratot is [6]. Az elmúlt 1-2 évtized során a mútéti technika rohamos fejlődésének lehettünk tanúi: a korábban alkalmazott nagy, váladékozó üreg hátrahagyásával járó petromastoidalis exenteratiós, illetve marsupialisatiós mútéteket felváltották a mütéti üregek zsírobliterációjával járó, a beteg számára sokkal jobb életminőséget jelentő agyalapi sebészeti megoldások. A mütéti technika helyes kiválasztása számos tényező függvénye, ezek közül az egyik legfontosabb a preoperatív arcidegfunkció. $\mathrm{Az}$ alkalmazott mútéti technikát a PPC kiterjedése határozza meg, a sebész végső döntését pedig a preoperatív HRCT/MRI felvételek alapos tanulmányozása kell, hogy megelözze.

Nem szabad szem elől téveszteni a korszerú implantológiai módszereket (cochlearis implantáció, BAHA) sem, melyek jól kombinálhatók a kiterjedt agyalapi sebészeti behatolásokkal [3, 9-12].

A PPC-k mind a diagnosztika, mind a sebészi kezelés szempontjából komoly kihívást jelentenek. Eredetüket illetően lehetnek iatrogén középfülmütét következményei, vagy létrejöhetnek szerzett cholesteatoma medialis irányú tovaterjedése során is. A congenitalis formák embrionális epithelmaradványok növekedése következtében jönnek létre [1]. A korszerü radiológiai módszerek (HRCT és MRI), valamint a múszerezettségben történő előrelépés (például endoszkópok használata, 3D mikroszkópok, robottechnika) nagy segítséget jelentenek a mütéti tervezést, a hatékony menedzsmentet illetően $[13,14]$.

A lateralis agyalapi sebészeti technikáknak az alábbi feltételeket kell teljesíteniük a PPC-k kezelése során: az ideális behatolásnak széles feltárást kell biztosítania a mátrix által roncsolt pars petrosa területre, ugyanakkor el kell érni azt, hogy az operatőr a mútét során kontrollálni tudja a dura matert, a nervus facialist, a sinus sigmoideust, a bulbus venea jugularist, valamint a carotis internát $[15,16]$.

\section{A PPC-k kezelésének mütéti algoritmusa}

A PPC-k kezelése során az alábbi tényezőket kell feltétlenül szem előtt tartani.

A) Törekedjünk a cholesteatomamátrix teljes eradikációjára.

B) Lehetőség szerint őrizzük meg az arcideg funkcióját.

C) Kerüljük el a dura mater sérülését és a következményes liquorrhoeát, illetve meningitist.

D) Törekedjünk a mütéti üreg obliterációjára (hasfali zsír).

E) Bár a hallás megőrzése másodlagos a mátrix radikális eltávolításához képest, kombinálhatjuk mútétjeinket a korszerű implantológiai módszerek szimultán vagy szekvenciális módon történő alkalmazásával.

A supralabyrinthaer PPC-k eseteiben, ha a patológia nem túl kiterjedt, és a hallás ép - tehát nincs fistula sem a cochlea basalis kanyarulatán, sem az ívjáratokon -, szóba jöhet a középsőskála-feltárás, esetenként transmastoid behatolással kombinálva. Ha viszont a betegnek már sensorineuralis halláscsökkenése van, vagy a HRCT alapján a basalis kanyarulaton fistulát feltételezünk, subtotalis petrosectomia (6. ábra), kiterjesztett translabyrinthaer behatolás vagy transoticus behatolás a választandó kezelési forma.

Az infralabyrinthaer PPC-k mútéti ellátása során a csontvezetést gyakran képesek vagyunk megőrizni, ilyenkor a subtotalis petrosectomia mellett törhetünk lándzsát a hallójárat, illetve a fülkürt lezárásával (8. ábra). Ritkán transmastoid behatolásra kerülhet sor, a retrolabyrinthaer régió kitakarításával. Ha a hallás eleve érintett, akkor transoticus behatolás javasolt.

$\mathrm{Az}$ infralabyrinthaer-apicalis és a masszín PPC-k eseteiben a hallás megőrzésére nagyon kevés az esély, következésképpen a mútéti behatolás kiválasztásában az arcideg funkciója kell, hogy vezérelje a sebészt. Ha ép az arcideg funkciója, akkor mindkét típusú cholesteatoma esetén a transoticus behatolás kecsegtethet sikerrel a mátrix maradéktalan eltávolítása szempontjából. Ha az arcideg funkciója érintett, akkor mindkét esetben dönthetünk a módosított transcochlearis behatolás mellett, ez a mútéti technika ugyanis jó rálátást biztosít a clivusra, a sinus sphenoidalisra, a rhinopharynxra, de még a sziklacsont csúcsára is. A módosított transcochlearis behatolás részeként (9. ábra) el kell végezni a nervus facialis posterior irányú mobilizálását („rerouting”); ami átmenetileg (6-10 hónap) facialis paralysissel jár, ugyanis ilyenkor sérül a ganglion geniculi környékének vérellátása (az arteria meningea media ága, az arteria petrosa profunda érintettsége). A betegeket azzal biztathatjuk, hogy 6-10 hónap elteltével a facialis funkció általában javul (maximum House-Brackmann III/VI. állapot érhető el). Ha a preoperatív arcidegfunkció ép, akkor a transoticus behatolás a választandó sebészi módszer. Tartsuk mindig szem előtt, hogy az arcidegfunkció érintettsége nemcsak funkcionális, hanem komoly pszichológiai hátrányt is jelent a beteg számára.

Ha a cholesteatomamátrix beterjed a sziklacsont csúcsába, akkor apicalis típusú PPC-ról beszélünk. Ilyenkor a beteg hallását és az arcideg funkcióját egyaránt szem előtt tartva az infratemporalis fossa B-típusú mútétre alapozhatunk, melyet kombinálhatunk a transoticus behatolással vagy a módosított transcochlearis behatolással (7. ábra).

\section{Irodalmi áttekintés}

Irodalmi áttekintésünket a PubMed adatbázisának használatával végeztük el. Kizárólag azokat a PPC-kal foglalkozó közleményeket vettük figyelembe, melyekben legalább 10 beteg adatait dolgozták fel. A következő kritériumokat vettük górcső alá: nómenklatúra, osztályozás, kezelési protokoll, pre- és posztoperatív arcidegfunkció, mútéttechnika, hallásmegőrzés, komplikációk, 
a betegség kiújulása. A beválasztási kritériumoknak 10 angol nyelvú közlemény felelt meg (2. táblázat), az öszszes betegszám 409 volt. A közleményeket összesítve, azok a halláscsökkenés mértékéről az összes beteg 70\%át, míg az arcidegbénulás tünetéről az összes beteg 58\%át érintően számoltak be.

A középsőskála-feltárást csupán néhány szerző [17, 18] alkalmazta kis kiterjedésú supralabyrinthaer PPC-k eseteiben, amikor a hallás megörzése volt a cél, és CT-vel előzetesen kizárták a basalis kanyarulat fistuláját. A posztoperatív hallásstatus alakulását egyik közlemény sem említi. Hawthorne és Fisch (1989) [17] meglepő módon szinte minden betegüknél észlelték a nervus facialis valamilyen mértékű érintettségét. Az általuk taglalt lehetséges teóriák a következók voltak: a) a ganglion geniculi környezetének ischaemiája; b) direkt kompresszió; c) emelkedett infrafunicularis nyomás; d) baktériumok és enzimek direkt toxikus hatása [7]. Sanna véleménye szerint az ismételt gyulladások és a direkt kompresszió vezethet az ideg egy részének kötőszövetes átépüléséhez [6]. Négy közlemény [17, 19-21] nem hasonlította öszsze a pre- és posztoperatív arcidegstatus alakulását. A további hat közlemény kumulatív statisztikai adatait összesítve kitűnt, hogy a House-Brackmann I-es típusú arcidegstatusszal rendelkező betegek $89 \%$-ának a mútét után sem romlott az arcidegfunkciója. Axon statisztikájá- ból kitűnik, hogy a prognózist illetően lényeges szempont, hogy az arcidegbénulás kezdetét követóen egy éven belül sor kerüljön a mütétekre [7]. Az egyéves időablak túlhaladása esetén Omran volt az első, aki facialishypoglossus anastomosist javasolt [5]. Napjainkban a legjobb posztoperatív eredményeket a facialis-masseter anastomosisoktól várhatjuk [8]. A 10 közlemény beteganyagát tekintve az esetek $2 \%$-ában fordult elő központi idegrendszeri szövődmény, melyek gyakorisági sorrendben a következők voltak: liquorcsorgás, meningitis, agytályog.

Az obliterációs (hasi zsír) mütéti technika bevezetésével a posztoperatív drenázs elhagyhatóvá vált, ugyanakkor megoldódott a létfontosságú képletek (arteria carotis interna, dura mater, nervus facialis, bulbus venae jugularis) védelme is. A vizsgált közlemények betegadatait elemezve megállapítható, hogy a perioperatív időszakban vagy a közvetlen posztoperatív időszakban halálozás nem fordult elö.

Az agyalapi sebészeti megoldások bevezetése (2015) óta a pécsi Klinikán kezelt 6 PPC-s esetrôl írt beszámolónk az első, ezzel a témával foglalkozó közlemény a hazai fülsebészeti irodalomban. A kórkép ritkasága okán nem könnyű felfedezni az összes cholesteatoma 3\%-át kitevő PPC-kat. A tünettan nem specifikus, a hagyományos középfülsebészeti megoldások pedig ebben a kór-

2. táblázat |A legalább 10, PPC-ban szenvedő beteg adatait feldolgozó közlemények az elmúlt 3 évtized szakirodalmában

\begin{tabular}{|c|c|c|c|c|c|c|}
\hline Szerző; év & Klasszifikáció & Esetszám & \multicolumn{2}{|c|}{$\begin{array}{l}\text { Mútét előtti } \\
\text { halláscsökkenés/arcidegbénulás }\end{array}$} & Recidíva & Komplikációk (esetszám) \\
\hline Charachon; 1989 & $\mathrm{~N} / \mathrm{A}$ & 42 & 35 & 15 & 6 & $\mathrm{~N} / \mathrm{A}$ \\
\hline Hawthorne és Fisch; 1989 & Fisch & 33 & $\mathrm{~N} / \mathrm{A}$ & 22 & 0 & $\begin{array}{l}\text { Meningitis (2) } \\
\text { Szívinfarktus (1) }\end{array}$ \\
\hline Pyle és Wiet; 1991 & Schuknecht & 10 & 8 & 5 & 3 & $\begin{array}{l}\text { Agyvízfolyás (1) } \\
\text { Sebfertőzés (1) } \\
\text { Mútéti üreg infekciója (4) }\end{array}$ \\
\hline Yanagihara; 1992 & $\mathrm{~N} / \mathrm{A}$ & 16 & 11 & 16 & 0 & $\mathrm{~N} / \mathrm{A}$ \\
\hline Axon; 1999 & Sanna & 25 & 16 & 14 & 5 & $\begin{array}{l}\text { Krónikus fülváladékozás }(3 / 6) \\
\text { Hallójárati stenosis }(2)\end{array}$ \\
\hline Magliulo; 2007 & Sanna & 52 & 36 & 28 & 4 & $\mathrm{~N} / \mathrm{A}$ \\
\hline Moffat; 2008 & Módosított Sanna & 43 & 26 & 22 & 2 & $\begin{array}{l}\text { Agyvízfolyás (4) } \\
\text { Sebfertőzés (1) } \\
\text { Epilepszia (1) } \\
\text { Mélyvénás trombózis (1) } \\
\text { Szeptikus szívinfarktus (1) }\end{array}$ \\
\hline Sanna; 2009 & Sanna & 129 & 82 & 68 & 5 & $\begin{array}{l}\text { Herniatio (1) } \\
\text { Mútéti üreg infekciója (2) } \\
\text { Agyvízfolyás és agytályog (1) }\end{array}$ \\
\hline Aubry; 2010 & Sanna & 28 & 27 & 10 & 8 & $\begin{array}{l}\text { Arcidegbénulás (4) } \\
\text { Hypoglossus paresis (2) } \\
\text { Vagus paresis (1) } \\
\text { Abducens paresis (1) }\end{array}$ \\
\hline Kim; 2014 & Sanna & 31 & 9 & 11 & 1 & $\begin{array}{l}\text { Arcidegbénulás (2) } \\
\text { Sebfertőzés (4) } \\
\text { Vertigo (1) }\end{array}$ \\
\hline
\end{tabular}

$\mathrm{N} / \mathrm{A}=$ nem volt adat megadva; $\mathrm{PPC}=$ pars petrosa cholesteatoma 
képben nem jelentenek végső megoldást. A valamennyi betegünket érintő halláspanaszt mi is képesek vagyunk már orvosolni korszerú implantológiai módszerek alkalmazásával. Beteganyagunkban az említett arcidegbénuláson felül egyéb peri- vagy korai posztoperatív komplikációt nem tapasztaltunk. Egy betegünknél a diffúziósúlyozott MRI cholesteatomamaradványt mutatott a carotis interna közelében. Ezen esetben további obszerváció mellett döntöttünk. Minden betegünk tekintetében lényeges javulást értünk el az életminőséget illetően.

\section{Következtetés}

A PPC-k diagnózisa és mútéti megoldása komoly kihívást jelent a klinikus számára. A diagnózis felállítását az alapos anamnézisfelvétel és a tünetek kapcsán korán felmerülő gyanú könnyíti meg, a diagnózist pedig a korszerü radiológiai módszerekre alapozhatjuk. Az agyalapi sebészeti behatolásoknak az elmúlt két évtized során tapasztalt fejlődése napjainkban már lehetővé teszi a pars petrosát roncsoló cholesteatoma mátrixának biztonságos és teljes mértékü eltávolítását. A cholesteatomasebészetben a mátrix radikális eltávolítása elsőbbséget élvez a hallás megőrzésével szemben. Indokolt esetekben - ha célunk a betegség teljes mértékü eradikálása - az oticus capsula teljes eltávolítására is sor kerülhet. A modern hallásrehabilitációs módszereket (BAHA, Bonebridge [Med-El, Innsbruck, Ausztria], cochlearis implantáció) az egyes mútéti behatolások során - szimultán vagy szekvenciális módon - sikerrel alkalmazhatjuk. A megfelelő sebészi behatolás megválasztását elősegíti, ha az operatőrök a PPC-k tekintetében közös nyelvet beszélnek, azaz ugyanazt a klasszifikációt használják. A sebészi ellátás során az arcideg különös figyelmet érdemel, hiszen az esetek jelentős részében az ideg érintettsége bizonyos mértékben kimutatható. Napjainkban már nem törekszünk radikális nyitott üregek hátrahagyására, hanem zsírobliterációt alkalmazva problémamentes mütéti üreget alakítunk ki. A betegek hosszú évekig történő követése elengedhetetlen része a menedzsmentnek.

Anyagi támogatás: A közlemény megírása, illetve a kapcsolódó kutatómunka anyagi támogatásban nem részesült.

Szerzői munkamegosztás: G. I.: A közlemény megírása, irodalmi kutatómunka végzése, ábraszerkesztés. T. I.: A kézirat és az irodalomjegyzék összeállítója, irodalmi kutatómunka. V. I.: Ábraszerkesztés. N. N., P. I.: Táblázatszerkesztés. R. P., B. P., Sz. I.: A kézirat szakmai véleményezése. R. T.: Radiológiai véleményezés. A cikk végleges változatát valamennyi szerző elolvasta és jóváhagyta.

Érdekeltségek: A szerzőknek nincsenek érdekeltségeik.

\section{Irodalom}

[1] Sanna M, Zini C, Gamoletti R, et al. Petrous bone cholesteatoma. Skull Base Surg. 1993; 3: 201-213.

[2] Michaels L. An epidermoid formation in the developing middle ear: possible source of cholesteatoma. J Otolaryngol. 1986; 15: 169-174.

[3] Bartels LJ. Facial nerve and medially invasive petrous bone cholesteatomas. Ann Otol Rhinol Laryngol. 1991; 100: 308-316.

[4] Pandya Y, Piccirillo E, Mancini F, et al. Management of complex cases of petrous bone cholesteatoma. Ann Otol Rhinol Laryngol. 2010; 119: 514-525.

[5] Omran A, De Denato G, Piccirillo E, et al. Petrous bone cholesteatoma: management and outcomes. Laryngoscope 2006; 116: 619-626.

[6] Sanna M, Pandya Y, Mancini F, et al. Petrous bone cholesteatoma: classification, management and review of the literature. Audiol Neurootol. 2011; 16: 124-136.

[7] Axon PR, Fergie N, Saeed SR, et al. Petrosal cholesteatoma: management considerations for minimizing morbidity. Am J Otol. 1999; 20: 505-510.

[8] Pavese C, Cecini M, Lozza A, et al. Rehabilitation and func tional recovery after masseteric-facial nerve anastomosis. Eur J Phys Rehabil Med. 2016; 52: 379-388.

[9] Piras G, Sanna M. Is middle fossa approach still indicated for cochlear implantation or should be replaced with subtotal petrosectomy? Otol Neurotol. 2019; 40: 694-695.

[10] Hernández S, Ospina JC, Gutiérrez-Gómez E, et al. Alternative techniques in cochlear implant surgery: subtotal petrosectomy. Am J Otol. 2020; 41: 102338.

[11] Altuna X, García L, Martínez Z, et al. The role of subtotal petrosectomy in cochlear implant recipients. Eur Arch Otorhinolaryngol. 2017; 274: 4149-4153.

[12] Linder T, Schlegel C, DeMin N, et al. Active middle ear implants in patients undergoing subtotal petrosectomy: new application for the Vibrant Soundbridge device and its implication for lateral cranium base surgery. Otol Neurotol. 2009; 30: 41-47.

[13] Mafee MF. MRI and CT in the evaluation of acquired and congenital cholesteatomas of the temporal bone. J Otolaryngol. 1993; 22: 239-248.

[14] Gourin CG, Terris DJ. Surgical robotics in otolaryngology: expanding the technology envelope. Curr Opin Otolaryngol Head Neck Surg. 2004; 12: 204-208.

[15] Fisch U, Mattox DE. (eds.) Microsurgery of the skull base. Georg Thieme Verlag, Stuttgart, 1988.

[16] Zanoletti E, Mazzoni A, Martini A, et al. Surgery of the lateral skull base: a 50-year endeavour. Acta Otorhinol Italica 2019; 39: S1-S146.

[17] Hawthorne M, Fisch U. The surgical management of supralabyrinthine and infralabyrinthine-apical cholesteatoma of the temporal bone. In: Fisch U, Valavanis A, Yaşargil MG. (eds.) Neurological surgery of the ear and the skull base. Kugler Publications, Amsterdam, 1989; pp. 11-19.

[18] Moffat D, Jones S, Smith W. Petrous temporal bone cholesteatoma: a new classification and long-term surgical outcomes. Skull Base 2008; 18: 107-115.

[19] Charachon R, Martin Ch, Gratacap B, et al. Temporal bone cholesteatoma. In: Fisch U, Valavanis A, Yaşargil MG. (eds.) Neurological surgery of the ear and the skull base. Kugler Publications, Amsterdam, 1989; pp. 21-28.

[20] Pyle GM, Wiet R. Petrous apex cholesteatoma: exteriorization versus subtotal petrosectomy with obliteration. Skull Base Surg. 1991; 1: 97--105.

[21] Yanagihara N, Nakamura K, Hatakeyama T. Surgical management of petrous apex cholesteatoma: a therapeutic scheme. Skull Base Surg. 1992; 2: 22-27.

(Tóth István dr., Pécs, Munkácsy M. u. 2., 7621 e-mail: drtoth.i7@gmail.com) 